\title{
PENGARUH DUKUNGAN KELUARGA TERHADAP MOTIVASI MAHASISWA REGULER MENJALANI PENDIDIKAN DI FAKULTAS KEPERAWATAN UNIVERSITAS SUMATERA UTARA
}

\author{
Siti Zahara Nasution, Widya Darayani Purba \\ Fakultas Keperawatan, Universitas Sumatera Utara, Medan 20155, Indonesia \\ E-mail: zahara_nasutioni@yahoo.co.id
}

\begin{abstract}
ABSTRAK
Tujuan penelitian: Penelitian ini bertujuan untuk mengidentifikasi pengaruh dukungan keluarga terhadap motivasi mahasiswa sarjana keperawatan kelas reguler menjalani pendidikan di Fakultas Keperawatan, Universitas Sumatera Utara. Metode: Metode kuantitatif dengan desain deskriptif korelasi digunakan dalam penelitian ini. Jumlah responden sebanyak 234 orang mahasiswa yang diambil dengan teknik proposional sampel. Pengumpulan data dilakukan dengan menggunakan tiga buah kuesioner sebagai instrumen penelitian yaitu kuesioner data demografi, kuesioner untuk mengukur dukungan keluarga yang telah diuji validitasnya $(0,98)$ dan reliabilitasnya $(0,82)$ dan kuesioner untuk mengukur motivasi mahasiswa yang telah diuji validitasnya $(0,89)$ dan reliabilitasnya $(0,80)$. Pengumpulan data dilakukan pada minggu kedua April sampai minggu kedua Mei 2015 setelah mendapatkan pernyataan lulus uji etik dari Komisi Etik Penelitian Kesehatan Fakultas Keperawatan USU. Teknik analisis data menggunakan uji korelasi Spearman. Hasil: Hasil penelitian menunjukkan adanya korelasi positif yang signifikan antara dukungan keluarga terhadap motivasi mahasiswa sarjana keperawatan kelas reguler menjalani pendidikan di Fakultas Keperawatan Universitas Sumatera Utara $\left(\rho_{\text {value }}=0,016\right)$, dengan nilai koefisien korelasi $r=0,157$ dengan interpretasi sangat lemah. Diskusi: Mayoritas mahasiswa memiliki dukungan keluarga yang baik, yaitu $98,3 \%$ dan mayoritas mahasiswa memiliki motivasi yang tinggi, yaitu $96,6 \%$, hal ini menunjukkan bahwa dukungan keluarga menciptakan motivasi yang baik bagi mahasiswa dalam mengikuti pembelajaran. Kesimpulan: Berdasarkan hasil penelitian, maka peneliti menyimpulkan bahwa terdapat pengaruh dukungan keluarga terhadap motivasi mahasiswa sarjana keperawatan kelas reguler menjalani pendidikan di Fakultas Keperawatan Universitas Sumatera Utara.

Kata Kunci : Mahasiswa, dukungan keluarga, motivasi.
\end{abstract}

\section{EFFECTS OF FAMILY SUPPORT ON MOTIVATION IN REGULAR STUDENTS UNDERTAKING THEIR STUDY AT THE FACULTY OF NURSING OF NORTH SUMATRA UNIVERSITY ABSTRACT}

Objective: This study aimed at identifying the effects of family support on motivation in nursing undergraduate students of regular class to undertake their study at the Education Faculty of Nursing, North Sumatra University. Methods: This study employed a quantitative method with correlation descriptive design. Total respondents were 234 students taken using proportional sampling. Data were collected using three questionnaires, namely demographic data questionnaire, questionnaire to measure family support of which validity (0.98) and reliability (0.82) had been tested and questionnaire to measure the motivation of students of which validity (0.89) and reliability (0.80) had been tested. The data were collected in the second week of April until the second week in May 2015 after obtaining the Ethical Clearance from the ethics committee for health research, the Faculty of Nursing, North Sumatra University. The data were analyzed using Spearman. Results: The results of the study indicated a significant positive correlation between family support and motivation in undergraduate nursing students of regular class undertaking study at the Faculty of Nursing, North Sumatra University $\left(\rho_{\text {value }}=\right.$ 0.016), with a correlation coefficient $r=0.157$ with very weak interpretation. Discussion: The majority of students received good family support (98.3\%) and the majority of students had high motivation (96.6\%). This suggests that family support creates good motivation for students in undertaking their study. Conclusion: Based on the research results, it can be concluded that there is a significant effect of family support on motivation in nursing undergraduate students of regular class undertaking their study at the Faculty of Nursing, North Sumatra University.

Keywords: student, family support, motivation 


\section{LATAR BELAKANG}

Bronson (2016) mendeskripsikan bahwa keluarga adalah unit terkecil dari masyarakat yang terdiri atas kepala keluarga dan beberapa orang yang berkumpul dan tinggal di suatu tempat di bawah suatu atap dalam keadaan saling ketergantungan. Di lingkup keluarga inilah pendidikan dimulai dan dari keluarga inilah akan tercipta tatanan masyarakat yang baik. Keluarga dijadikan sebagai unit yang utama karena keluarga saling berkaitan, saling memengaruhi antara sesama anggota keluarga dan akan memengaruhi pula keluarga-keluarga yang ada di sekitarnya atau masyarakat sekitarnya serta dalam konteks yang lebih luas berpengaruh terhadap negara.

Salah satu faktor motivasi dan keberhasilan seseorang ialah dukungan keluarga. Dukungan keluarga diharapkan dapat meningkatkan motivasi mahasiswa dalam menjalani pendidikan keperawatan dan mencintai jurusannya yang sehingga setelah menyelesaikan pendidikannya mahasiswa tersebut akan menjadi perawat profesional. Friedman \& Benden (2010) mengatakan bahwa dukungan keluarga adalah sikap, tindakan, dan penerimaan keluarga terhadap anggota keluarga. Anggota keluarga memandang bahwa orang yang bersifat mendukung selalu siap memberikan pertolongan dan bantuan jika diperlukan karena setiap individu memiliki kondisi internal, kondisi internal tersebut turut berperan dalam aktivitas dirinya sehari-hari. Salah satu kondisi internal tersebut adalah motivasi. Purwanto (2007) mengatakan bahwa motivasi adalah segala sesuatu yang mendorong seseorang untuk melakukan sesuatu. Deci (2016) berpendapat bahwa dorongan ini berada pada diri seseorang yang menggerakkan untuk melakukan sesuai dengan dorongan dalam dirinya. Motivasi juga dapat dikatakan sebagai perbedaan antara dapat dan mau melaksanakan. Guido, dkk. (2016) menjelaskan bahwa motivasi lebih dekat pada mau melaksanakan tugas untuk mencapai tujuan. Motivasi adalah kekuatan, baik dari dalam maupun luar yang mendorong seseorang untuk mencapai tujuan tertentu yang telah ditetapkan sebelumnya.

Andari CIP (2013) dalam penelitiannya tentang faktor-faktor yang berhubungan dengan motivasi mahasiswa memilih profesi bidan menemukan bahwa dukungan keluarga yang tinggi menjadikan mahasiswa memiliki motivasi yang tinggi dan dukungan keluarga yang rendah memiliki motivasi yang tinggi juga. Dengan demikian, adanya dukungan keluarga atau tidak motivasi mahasiswa tetap tinggi. Namun, motivasi akan lebih tinggi jika mendapatkan dukungan keluarga. Pernyataan ini diperkuat oleh teori Friedman tentang dukungan keluarga yang bermakna keluarga memandang bahwa orang yang bersifat mendukung selalu siap memberikan pertolongan dan bantuan jika diperlukan. Adanya dukungan dari keluarga maka akan meningkatkan motivasi mahasiswa dan karena dukungan keluarga, mahasiswa juga semakin semangat untuk meraih cita-cita sehingga membanggakan orangtuanya.

Fenomena yang sering terjadi di Fakultas Keperawatan ialah banyak mahasiswa memilih jurusan tanpa dukungan keluarga, mengikuti keinginan keluarga, atau terpaksa memilih jurusan yang tidak sesuai dengan keinginan karena tidak lulus tes masuk perguruan tinggi dan karena ikut-ikutan dengan teman-temannya. Hal tersebut dapat memengaruhi motivasi dan keseriusan mahasiswa dalam menjalani pendidikan. Akibatnya, sering muncul masalah saat sudah menjadi mahasiswa keperawatan, seperti sering sulit memahami materi karena banyaknya materi kuliah, tidak ada kesiapan dalam mengikuti ujian blok, sering bolos 
kuliah karena tidak menyukai mata kuliahnya, sulit mengatur jadwal istirahat sehingga banyak yang sakit karena perkuliahan yang padat, jadwal skill laboratorium yang tak tentu, praktikum, dan sebagian mahasiswa bertempat tinggal jauh dari orangtua sehingga membuat terus memikirkan liburan agar dapat kembali ke kampung halaman. Oleh karena itu, sangat diperlukan dukungan keluarga untuk meningkatkan motivasi mahasiswa menjalani pendidikan dan menghadapi banyak masalah dalam perkuliahan.

\section{METODE}

Desain penelitian yang digunakan ialah deskripsi korelasi yang bertujuan untuk mengidentifikasi pengaruh dukungan keluarga terhadap motivasi mahasiswa menjalani pendidikan di Fakultas Keperawatan USU (Gambar 1).

Populasi dalam penelitian ini ialah mahasiswa sarjana keperawatan kelas reguler berjumlah 566. Pada semester 2 berjumlah 137, semester 4 berjumlah 165 , semester 6 berjumlah 134, dan semester 8 berjumlah 130 karena masih menjalani pendidikan di FKep USU.

Jumlah sampel pada penelitian ini ditentukan dengan rumus:

$$
\begin{aligned}
& \mathrm{n}=\frac{N}{N(e)^{2}+1} \\
& \mathrm{n}=\frac{566}{566(0,05)^{2}+1} \\
& \mathrm{n}=\frac{566}{2,415} \quad=234 \text { orang } \\
& \mathrm{n}=234,36 \quad
\end{aligned}
$$

Pengambilan sampel dalam penelitian ini menggunakan metode proporsional sampel, yaitu peneliti mengambil responden sesuai dengan proporsi yang telah diterapkan peneliti per angkatan, yaitu semester 2, semester 4, dan semester 6 , kemudian setiap angkatan yang telah ditetapkan jumlahnya diambil untuk jadi responden dengan cara acak atau random.

Metode pengumpulan data yang digunakan adalah menggunakan tiga buah kuesioner yang dibuat sendiri oleh peneliti berdasarkan referensi dari Friedman \& Benden (2010), yaitu kuesioner data demografi, kuesioner tentang dukungan keluarga dan kuesioner motivasi mahasiswa menjalani pendidikan di Fakultas Keperawatan USU. Kuesioner untuk mengukur dukungan keluarga yang telah diuji validitasnya $(0,98)$ dan reliabilitasnya $(0,82)$ dan kuesioner untuk mengukur motivasi mahasiswa yang telah diuji validitasnya $(0,89)$ dan reliabilitasnya $(0,80)$. Instrumen Kuesioner dukungan keluarga terhadap motivasi mahasiswa menjalani pendidikan di FKep USU akan dikategori berdasarkan rumus statistik menurut Hidayat (2007).

$$
i=\frac{\text { rentang }}{\text { banyak kelas }}
$$

i merupakan panjang kelas dengan rentang (nilai tertinggi dikurangi nilai terendah) nilai tertinggi sebesar 64 , nilai terendah 16 dengan 2 kategori banyak kelas sehingga diperoleh panjang kelas sebesar 24. Data untuk kuesioner dukungan keluarga, dikategorikan sebagai berikut:

$$
\begin{array}{ll}
\text { Baik } & =41-64 \\
\text { Kurang } & =16-40
\end{array}
$$

Kuesioner motivasi berjumlah 8 pernyataan dengan berdasarkan tinjauan pustaka tentang konsep teori Frederich Herzberg (2002) yang membagi teori motivasi yang bersumber dari dalam diri seseorang antara lain prestasi yang diraih 
(achievement) pada butir pernyataan nomor 1,5 , pengakuan orang lain (recognition) pada butir pernyataan nomor 2, 6, tanggung jawab (responsibility) pada butir pernyataan nomor 3,7 , dan pengembangan (advancement) pada butir pernyataan nomor 4,8 . Kuesioner ini disusun dalam bentuk 4 pertanyaan positif pada pernyataan nomor 1-4 dan 4 negatif pada pernyataan nomor 5-8. Penelitian ini menggunakan skala Guttman dengan dua pilihan alternatif jawaban yang terdiri atas $\mathrm{Ya}$ dan Tidak. Bobot nilai yang diberikan untuk pertanyaan positif, ya bernilai 1 dan tidak bernilai 0 . Pertanyaan negatif jika ya bernilai 0 dan tidak bernilai 1 .

Kuesioner motivasi mahasiswa menjalani pendidikan di FKep USU akan dikategori berdasarkan rumus statistik menurut Hidayat (2007).

$$
i=\frac{\text { rentang }}{\text { banyak kelas }}
$$

Panjang kelas adalah nilai tertinggi dikurangi nilai terendah, nilai tertinggi sebesar 8, nilai terendah 0 dengan 2 kategori maka, didapatlah panjang kelas 4 .

Data untuk kuesioner motivasi dikategorikan sebagai berikut.

$$
\begin{array}{ll}
\text { Tinggi } & =4-8 \\
\text { Rendah } & =0-3
\end{array}
$$

Pengumpulan data dilakukan pada minggu keduaApril sampai minggu kedua Mei 2015 setelah mendapatkan pernyataan lulus uji etik dari Komisi Etik Penelitian Kesehatan Fakultas Keperawatan USU. Prosedur pengumpulan data dilakukan setelah mengajukan permohonan izin pelaksanaan penelitian institusi pendidikan (Fakultas Keperawatan Universitas Sumatera Utara) setelah mendapatkan balasan surat izin melakukan penelitian, kemudian peneliti meminta izin kepada ketua kelas masing- masing. Peneliti akan menentukan calon responden yang sesuai dengan kriteria yang telah ditentukan sebelumnya. Setelah mendapatkan calon responden, selanjutnya peneliti menjelaskan kepada calon responden mengenai tujuan, manfaat, dan prosedur pelaksanaan penelitian, lalu calon responden yang bersedia menandatangani surat persetujuan informed consent untuk ikut serta dalam penelitian yang akan dilaksanakan. Peneliti mengambil data dari responden dengan cara memberikan kuesioner kepada responden dan responden diminta menjawab lembar isian kuesioner. Responden juga diberi kesempatan untuk bertanya tentang pertanyaan yang tidak dipahami. Setelah responden selesai mengisi kuesioner, peneliti kemudian memeriksa kelengkapan data dan data yang kurang lengkap dapat segera dilengkapi. Data yang sudah terkumpul selanjutnya diolah dan dianalisis univariat dan bivariat dengan menggunakan Spearmen digunakan untuk menguji korelasi antara dukungan keluarga yang bersifat skala ordinal dan motivasi yang datanya bersifat skala ordinal.

\section{HASIL}

Pada Tabel 1 berikut dapat dilihat bahwa karakteristik responden berdasarkan jenis kelamin mayoritas mahasiswa keperawatan berjenis kelamin perempuan $(n=201$ atau $85,9 \%)$, responden pada semester 4 berjumlah lebih banyak ( $n=68$ atau $29,1 \%$ ), sebagian besar mahasiswa bertempat tinggal di kos ( $n=134$ atau $57,3 \%$ ); berdasarkan tingkat pendidikan orangtua, pendidikan terakhir orangtua (ayah) terbanyak adalah SMA ( $n=107$ atau 45,7\%), demikian juga pendidikan orangtua (ibu) terbanyak adalah SMA $(n=104$ atau $44,4 \%)$, yang berarti bahwa tingkat pendidikan orangtua dalam penelitian ini tidak terlalu berbeda antara ayah dan ibu. Mayoritas responden memiliki penghasilan 
keluarga per bulan > Rp1.625.000,00 ( $\mathrm{n}=194$ mahasiswa memiliki penghasilan keluarga di atau $82,9 \%$ ), yang berarti bahwa mayoritas atas UMR Kota Medan.

Tabel 1. Karakteristik responden

\begin{tabular}{|c|c|c|}
\hline Karakteristik & Frekuensi & Persentase \\
\hline \multicolumn{3}{|l|}{ Jenis kelamin } \\
\hline - Laki-laki & 33 & $14,10 \%$ \\
\hline - Perempuan & 201 & $85,90 \%$ \\
\hline \multicolumn{3}{|l|}{ Semester } \\
\hline - Dua & 57 & $24,36 \%$ \\
\hline - Empat & 68 & $29,06 \%$ \\
\hline - Enam & 55 & $23,50 \%$ \\
\hline - Delapan & 54 & $23,08 \%$ \\
\hline \multicolumn{3}{|l|}{ Tempat tinggal } \\
\hline - Bers. orangtua & 64 & $27,35 \%$ \\
\hline - Kos & 134 & $57,27 \%$ \\
\hline - Bers.saudara & 30 & $12,82 \%$ \\
\hline - Asrama & 6 & $2,56 \%$ \\
\hline \multicolumn{3}{|l|}{ Pendidikan ayah } \\
\hline - Tidak sekolah & 0 & 0 \\
\hline - SD & 13 & $5,55 \%$ \\
\hline - SMP & 24 & $10,26 \%$ \\
\hline - SMU & 107 & $45,74 \%$ \\
\hline - Perguruan tinggi & 90 & $38,45 \%$ \\
\hline \multicolumn{3}{|l|}{ Pendidikan ibu } \\
\hline - Tidak sekolah & 1 & $0,43 \%$ \\
\hline - SD & 13 & $5,56 \%$ \\
\hline - SMP & 25 & $10,68 \%$ \\
\hline - SMU & 104 & $44,44 \%$ \\
\hline - Perguruan tinggi & 91 & $39,89 \%$ \\
\hline \multicolumn{3}{|l|}{ Penghasilan keluarga } \\
\hline < Rp.1.650.000 & 40 & $17,10 \%$ \\
\hline$>$ Rp. 1.650 .000 & 194 & $82,90 \%$ \\
\hline
\end{tabular}

Berdasarkan Tabel 2 berikut ini, variabel pada dukungan keluarga kurang. Variabel B A menunjukkan bahwa mayoritas responden, menunjukkan bahwa motivasi mahasiswa/i yaitu sebanyak 230 orang $(98,3 \%)$ menjalani pendidikan sebanyak 226 orang dikategorikan pada dukungan keluarga baik, (96,6\%) memiliki motivasi yang tinggi dan 8 sementara 4 orang $(1,7 \%)$ dikategorikan orang $(3,4 \%)$ memiliki motivasi rendah. 
Tabel 2. Distribusi frekuensi dukungan keluarga dan motivasi mahasiswa

\begin{tabular}{lccc}
\hline & Variabel & Jumlah & Persentase \\
\hline A. Dukungan & A. Dukungan Keluarga Baik & 230 & $98,3 \%$ \\
Keluarga & Dukungan Keluarga Kurang & 4 & $1,7 \%$ \\
B. Motivasi & B. Motivasi Tinggi & 226 & $96,6 \%$ \\
Mahasiswa & Motivasi Rendah & 8 & $3,4 \%$ \\
\hline
\end{tabular}

Hasil analisis pada Tabel 3 menunjukkan pendidikan keperawatan di Fakultas bahwa ada pengaruh dukungan keluarga Keperawatan Universitas Sumatera Utara terhadap motivasi mahasiswa sarjana dengan nilai $p=0,016$. keperawatan kelas reguler menjalani

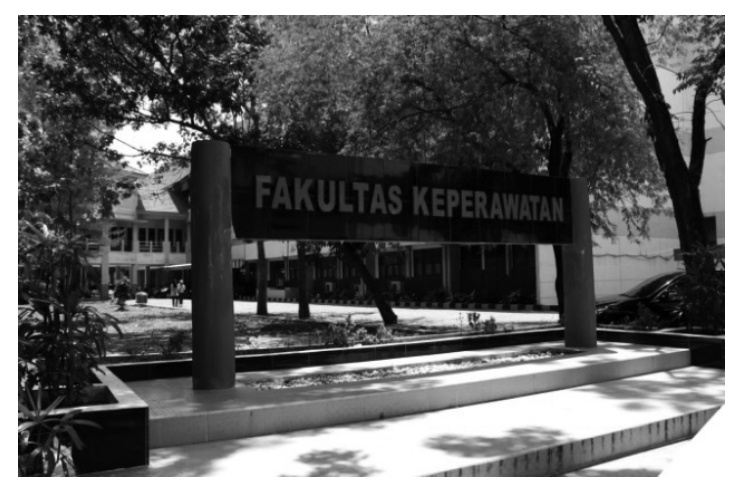

Gambar 1. FKep USU beralamat di JI. Prof. Ma'as No. 3 Kampus Universitas Sumatera Utara, Medan

\section{DISKUSI}

Berdasarkan data hasil penelitian yang diperoleh, pembahasan dilakukan untuk mengetahui pengaruh dukungan keluarga terhadap motivasi mahasiswa sarjana keperawatan kelas reguler dalam menjalani pendidikan keperawatan di Fakultas Keperawatan Universitas Sumatera Utara.

Dukungan Keluarga Mahasiswa Sarjana Keperawatan Kelas Reguler Menjalani Pendidikan Keperawatan di Fakultas Keperawatan Universitas Sumatera Utara

Tabel 3. Analisis Pengaruh dukungan keluarga terhadap motivasi mahasiswa

\begin{tabular}{|c|c|c|c|c|}
\hline Variabel 1 & Variabel 2 & $\mathbf{P}$ & $\mathbf{r}$ & Keterangan \\
\hline $\begin{array}{l}\text { Dukungan keluarga } \\
\text { mahasiswa keperawatan } \\
\text { kelas reguler menjalani } \\
\text { pendidi kan keperawatan } \\
\text { di FKep USU }\end{array}$ & $\begin{array}{l}\text { Motivasi mahasiswa } \\
\text { keperawatan kelas } \\
\text { reguler menjalani } \\
\text { pendidikan keperawatan } \\
\text { di FKep USU }\end{array}$ & 0,016 & 0,157 & $\begin{array}{l}\text { Pengaruh positif } \\
\text { dengan interpretasi } \\
\text { lemah }\end{array}$ \\
\hline
\end{tabular}

Berdasarkan hasil distribusi frekuensi dukungan keluarga menyimpulkan bahwa mahasiswa memiliki dukungan keluarga dengan kategori baik 226 orang $(96,6 \%)$ dan kategori kurang 4 orang (1,7\%). Hal ini dapat diasumsikan bahwa dukungan keluarga pada responden memiliki dukungan keluarga yang baik. Hasil ini sejalan dengan penelitian 
Yanti (2012) bahwa dukungan keluarga yang diperoleh mahasiswa sangat tinggi $(69,3 \%)$ dapat diartikan bahwa mahasiswa selama ini mendapatkan dukungan keluarga yang sangat baik dari orangtuanya dalam memotivasi anaknya menjalani pendidikan difakultas keperawatan untuk menjadi perawat.

Dukungan keluarga dapat diberikan melalui dukungan emosional, dukungan instrumental, dan dukungan informasi. Dengan adanya dukungan keluarga, kesejahteraan psikologis seseorang juga akan meningkat karena adanya perhatian, pengertian, atau menimbulkan perasaan memiliki, meningkatkan harga diri, dan memiliki perasaan positif mengenai dirinya (Weiten,1992). Akan tetapi, jika dukungan keluarga rendah, itu akan memberikan efek yang negatif yang dapat menyebabkan mereka tidak memiliki semangat dalam menjalani pendidikan, tidak ada dorongan untuk mengikuti kuliah, pendidikan terbengkalai, dan hal-hal negatif lain yang memengaruhi pendidikan. Oleh karena itu, dukungan dari keluarga terhadap mahasiswa sangat besar pengaruhnya untuk meningkatkan keyakinan diri dengan memiliki perasaan positif mengenai dirinya untuk menjalani perkuliahan.

Menurut Purwanto (2007), keadaan keluarga memengaruhi anak dalam menjalani pendidikan/perkuliahan. Keadaan tersebut meliputi ada yang berasal dari keluarga miskin atau kaya, keluarga dengan suasana tenteram dan damai atau sebaliknya, berjarak jauh ataupun dekat, ada keluarga ayah-ibu yang terpelajar atau kurang pengetahuan, ada keluarga yang mempunyai cita-cita tinggi bagi anakanaknya, ada pula yang biasa saja. Suasana dan keadaan keluarga yang bermacammacam tersebut menentukan bagaimana dan sampai di mana dukungan keluarga sangat memengaruhi dalam menjalani pendidikan. Termasuk ada tidaknya atau tersedia tidaknya fasilitas yang diperlukan turut memegang peranan penting.

Responden pada penelitian ini mayoritas berjenis kelamin perempuan sebanyak 201 orang $(85,9 \%)$. Hal ini sejalan dengan hasil penelitian Siswanto (2014). Di lapangan ditemukan bahwa mayoritas mahasiswa Program Studi IImu Keperawatan Riau berjenis kelamin perempuan yaitu lebih dari $50 \%$. Profesi keperawatan yang didominasi kaum perempuan disebabkan oleh sikap dasar perempuan identik sebagai sosok yang ramah, sabar, telaten, lemah lembut, dan dianggap memiliki naluri keibuan serta sifat caring (peduli, hormat, dan menghormati orang lain) yang harus dimiliki setiap profesi.

Pambudi PS dan Wijayanti DY (2012) menyatakan bahwa sifat-sifat ini dimiliki oleh kaum perempuan sehingga banyak orang beranggapan bahwa profesi keperawatan identik dan dianggap sesuai untuk kaum perempuan. Dalam hal ini dapat diartikan perempuan cenderung meminati jurusan keperawatan daripada laki-laki. ClarkeStewart, AC \& Allhusen, VD (2005) berpendapat bahwa perlakuan orangtua, terutama dalam hubungan antara ibu dan anak berpengaruh terhadap pendidikan anak. Dalam menjalani pendidikan atau mencapai prestasi, anak dipengaruhi oleh hubungan akrab antara orangtua, terutama hubungan ibu dengan putrinya. Hubungan akrab antara ibu dan putrinya dapat diciptakan seperti sering mengajak berbincangbincang anaknya terkait masalah-masalah yang dialaminya, sering memberikan hiburan kepada anaknya, memberi pujian, pertolongan, dan keterangan-keterangan, serta mengajari cara menghadapi berbagai persoalan. 
Pendidikan terakhir orangtua pada penelitian ini mayoritas SMA. Pendidikan merupakan salah satu faktor penting yang dapat mengarahkan pendidikan anaknya secara baik. Fandoli (2014) berpendapat bahwa cara orangtua mendidik anaknya didasarkan pada pengalaman pendidikan yang ditempuh orangtua. Semakin tinggi pendidikan orangtua, akan lebih mudah mengarahkan dan mendukung anak dalam menjalani pendidikan. Namun, menurut Wulandari (2014) keluarga yang memiliki tingkat pendidikan rendah dan merasa kurang sukses dengan yang diperolehnya saat ini terkadang justru mampu menciptakan dukungan yang lebih baik anak agar berprestasi. Mereka ingin melihat anaknya memiliki cita-cita yang tinggi dan ingin menciptakan anak yang lebih berkualitas darinya. Penelitian ini menunjukkan bahwa dukungan keluarga yang baik diberikan oleh orangtua yang tingkat pendidikannya tinggi dan yang tingkat pendidikannya tidak tinggi.

Penghasilan orangtua juga dapat memengaruhi dukungan keluarga. Dengan penghasilan lebih tinggi, mereka dapat memenuhi kebutuhan anak dalam membiayai uang kuliah dan memenuhi perlengkapan/ memfasilitasi kebutuhkan anak yang dapat mendukung motivasi anak dalam menjalani pendidikannya. Hal ini juga dapat dibuktikan bahwa mayoritas orangtua berpenghasilan $>$ Rp1.650.000,00 sebanyak 194 orang $(82,9 \%)$.

Motivasi Mahasiswa Sarjana Keperawatan Kelas Reguler Menjalani Pendidikan Keperawatan di Fakultas Keperawatan Universitas Sumatera Utara

Berdasarkan hasil penelitian ini, mahasiswa yang memiliki motivasi tinggi 226 orang $(96,6 \%)$. Hal ini menunjukkan bahwa motivasi atau dorongan/keinginan mahasiswa dalam menjalani pendidikan tinngi. Hasil penelitian tersebut sesuai dengan pendapat Azwar (2009) yang menyatakan bahwa banyak faktor yang memengaruhi keberhasilan dalam proses pembelajaran/menjalani pendidikan, salah satunya motivasi. Motivasi sangat penting untuk menghindarkan para mahasiswa dari kegagalan.

Motivasi adalah dorongan individu atau seseorang untuk berbuat/mengerjakan sesuatu dengan tujuan memenuhi kebutuhannya. Motivasi merupakan faktor pendorong manusia untuk bertingkah laku dalam mencapai kebutuhan atau sesuatu yang dicita-citakan. Hasil penelitian ini juga sejalan dengan pendapat Safitri (2013) yang mendeskripsikan bahwa motivasi yang tinggi dapat memengaruhi sikap mahasiswa dalam menjalani pendidikan, terutama dalam pencapaian prestasi. Peneliti berasumsi bahwa motivasi berfungsi untuk menimbulkan, mendasari, mengarahkan, dan dapat menentukan baik atau tidaknya sikap dalam mencapai tujuan sehingga semakin besar harapan kesuksesan dalam menjalani pendidikan.

Seseorang yang besar motivasinya akan giat berusaha, tampak gigih, dan tidak menyerah dengan hambatan ataupun masalah yang dihadapi dalam mernjalani pendidikan dan apabila motivasi melemah, keinginan untuk menjalani pendidikan menurun sehingga mengakibatkan mahasiswa sering bolos kuliah, tidak mengerjakan tugas yang diberikan oleh dosen, tidak bersemangat mengikuti perkuliahan, nilai-nilai yang dicapai rendah, dan selalu mengikuti remedial ataupun grand remedial. Oleh karena itu, mahasiswa perlu diperkuat terus-menerus dengan unsurunsur yang dapat memengaruhi motivasi.

Dimyati dan Mudjiono (2006) mendeskripsikan bahwamotivasidipengaruhi oleh (1) cita-cita yang ingin dicapainya, (2) 
didukung pencapaian kemampuannya yang pernah dilakukan dengan meningkatkan percaya dirinya, (3) kondisi kesehatan jasmani dan rohani, (4)kondisi lingkungannya seperti keadaan tempat tinggal. Dalam penelitian ini, mayoritas responden tinggal di kos/tinggal jauh dari orangtua, biasanya bersama teman sebaya/teman satu jurusan. Mereka biasanya dipengaruhi teman sebaya. Jika, memiliki teman sebaya yang membawa pengaruh positif maka akan memberikan dukungan dan dapat memperkuat motivasi dalam pencapaian keberhasialam dan sebaliknya, jika memiliki teman sebaya yang membawa pengaruh negatif maka akan terpengaruh kedalam hal-hal negatif. Oleh karena itu, kondisi lingkungan di kampus, kerukunan dalam keluarga, ketertiban pergaulan perlu dipertinggi mutunya dengan lingkungan yang aman, tentram dan tertib.

Guido, dkk. (2016) menjelaskan bahwa unsur-unsur dinamis dalam belajar dan pembelajaran seperti perasaan memiliki kemauan, ingin mendapatkan perhatian dan dukungan dari keluarganya, dan pikiran yang mengalami perubahan berkat pengalaman hidup. Unsur-unsur tersebut dapat memengaruhi pencapaian tujuan agar mahasiswa memiliki motivasi yang kuat sehingga dalam menjalani pendidikan tidak mengalami hambatan.

\section{Pengaruh Dukungan Keluarga terhadap Motivasi Mahasiswa Sarjana Keperawatan Kelas Reguler Menjalani Pendidikan di Fakultas Keperawatan Universitas Sumatera Utara}

Hasil penelitian ini menunjukkan bahwa dukungan keluarga terhadap motivasi mahasiswa sarjana keperawatan kelas reguler menjalani pendidikan di Fakultas Keperawatan Universitas Sumatera Utara memiliki hubungan yang signifikan, dilihat dari nilai $\rho=0,016$ yang berada di bawah level of significant $\alpha=0,05$ dengan arah hubungan positif dengan kekuatan hubungan sangat lemah $(r=0,157)$. Artinya, semakin baik dukungan keluarga, semakin tinggi motivasi.

Hasil penelitian ini sejalan dengan penelitian Suyasa, dkk. (2014) dengan judul "Hubungan antara Dukungan Keluarga dengan Motivasi Belajar Mahasiswa Program Studi IImu Keperawatan (PSIK) Fakultas Keperawatan", bahwa terdapat korelasi positif antara dukungan keluarga dan motivasi. Artinya, semakin baik dukungan keluarga, semakin tinggi motivasi. Penelitiannya menguraikan bahwa ada pengaruh antara dukungan keluarga dan motivasi. Keduanya memiliki hubungan yang erat karena tanpa ada dukungan keluarga, mahasiswa akan sulit untuk meningkatkan motivasi belajarnya. Keluarga memiliki peranan penting dalam mendukung apa yang dilakukan oleh mahasiswa itu sendiri seperti keluarga sangat mengetahui apa yang dibutuhkan oleh mahasiswa, berperan penting dalam membantu memecahkan masalah yang dihadapi oleh mahasiswa, memberi masukan-masukan, dan memberikan semangat untuk mencapai tujuan yang ingin dicapai.

Partini dan Rivai (2013) dalam penelitiannya yang berjudul "Peran Keluarga Inti dalam Menumbuhkan Motivasi Belajar" menyatakan bahwa ada korelasi positif yang signifikan antara dukungan keluarga dan motivasi. Artinya, semakin baik dukungan keluarga seseorang, semakin tinggi motivasinya. Penelitiannya lebih dikhususkan pada dukungan yang diberikan keluarga inti (kedua orangtua) karena dalam menumbuhkan motivasi dalam pendidikan juga diperlukan lingkungan kondusif di rumah yang menjadi tanggung jawab seluruh anggota keluarga inti, terutama orangtua (ayah dan ibu). Bentuk dukungan 
berupa nasihat, perhatian, kasih sayang, penyediaan fasilitas, dan pujian. Dukungan ini dapat diberikan dengan cara melihat hasil belajar anak dan mengevaluasinya.

Helkers dan Wosnitza (2016) dalam penelitiannya menemukan bahwa dukungan dan komitmen dari keluarga yang baik terhadap pendidikan anak akan membuat anak memiliki motivasi yang tinggi dalam meraih prestasi yang baik dalam akademi untuk mewujudkan keinginannya dan keinginan keluarganya untuk prestasi yang memuaskan, karena seharusnya dukungan keluarga juga penting untuk memberikan motivasi kepada anak agar dapat membedakan hal-hal yang positif dan negatif. Dukungan dari keluarga maka juga akan meningkatkan motivasi mahasiswa dan dengan adanya dukungan keluarga, mahasiswa juga semakin bersemangat untuk meraih cita-cita sehingga membanggakan orang tuanya.

\section{SIMPULAN}

Hasil penelitian ini menunjukkan bahwa mahasiswa yang memiliki dukungan keluarga yang baik sejumlah 230 orang $(98,3 \%)$, sementara 4 orang $(1,7 \%)$ dikategorikan pada dukungan keluarga kurang, dalam menjalani pendidikan keperawatan di Fakultas Keperawatan Universitas Sumatera Utara. Sejumlah 226 orang $(96,6 \%)$ mahasiswa berada dalam kategori motivasi yang tinggi dan 8 orang $(3,4 \%)$ memiliki motivasi rendah dalam menjalani pendidikan keperawatan di Fakultas Keperawatan Universitas Sumatera Utara.

Diharapkan dukungan keluarga semakin lebih baik lagi agar motivasi mahasiswa dalam menjalani pendidikan akan semakin tinggi dan akhirnya mahasiswa dapat berprestasi tinggi. Dukungan keluarga yang tinggi memberikan efek motivasi yang tinggi dalam menjalani pendidikan yang dapat menjadikan seorang mahasiswa menjadi seorang perawat profesional. Mereka akan memberikan pelayanan dan asuhan keperawatan yang semakin baik.

\section{DAFTAR PUSTAKA}

Andari CIP (2013). Faktor-faktor Yang Berhubungan Dengan Motivasi Mahasiswa Memilih Profesi Bidan Stikes U'budiyah Banda Aceh. http://simtakp.uii. ac.id/dockti/CUT_IRA_PUTRI_ANDARIkti.pdf. Diakses tanggal 21 Maret 2016. Azwar. (2009). Prinsip-prinsip Kesehatan. Binarupa Aksara Cipta, Jakarta.

Bronson. (2016) "Autonomy Support Environtment and Autonomous Motivation on Nursing Student Academic Performance: An Exploratory Analysis". Nurse Education Today, Volume 44, September 2016, pages 103-108.

Clarke-Stewart, AC \& Allhusen, VD. (2005) What we know about children. http:// www.hup.harvard.edu. Diakses tanggal 14 Juni 2015.

Deci, E.L. (2016) Intrinsic motivation and Self-Determination. Reference Module in Neuroscience and Biobehavioral Psychology, 2017.

Dimyati dan Mudjiono. (2006). Belajar dan Pembelajaran. Rineka Cipta, Jakarta.

Fandoli, A. (2014) Hubungan Prestasi Belajar siswa dan Tingkat Pendidikan Orangtua dengan Minat Melanjutkan Pendidikan Ke Perguruan Tinggi di Bidang Keperawatan. https://digilib.uns. ac.id/dokumen/detail/42613/HubunganPrestasi-Belajar-Siswa-Dan-TingkatPendidikan-Orang-Tua-Dengan-MinatMelanjutkan-Pendidikan-Ke-PerguruanTinggi-Di-Bidang-Keperawatan. Diakses tanggal 16 Juni 2015.

Friedman, M.M, Benden, V.R(2010). Buku Ajar Keperawatan Keluarga Riset, Teori dan Praktek. Edisi 5. EGC, Jakarta. 
Guido, G, Pino, G, Peluso, A.M. (2016). "Assessing Individuals' Re-gifting Motivation". Journal of Business Research, Volume 69, Issue 12, December 2016, pages 5956-5963.

Hidayat, A.A.A (2007). Metode Penelitian Keperawatan dan Teknik Analisa Data. Jakarta: Salemba Medika.

Helker, K. Wosnitza, M. (2016). "The Interplay of Students' and Parents' Responsibility Judgements in the school Context and Their Associations with Student Motivation and Achievement". http://www.sciencedirect.com/science/ article/pii/S0883035515301373. Diakses tanggal 18 Juni 2015.

Hezberg, F (2002) Teori Motivasi: Teori 2 Faktor http://www. lib.ui.ac.id. Diakses tanggal 12 Maret 2015.

Partini dan Rivai, Z.A. (2013) Peran Keluarga Inti dalam Menumbuhkan Motivasi Belajar Remaja. https://publikasiilmiah. ums.ac.id/bitstream/handle/11617/3972/ A24. pdf?sequence $=1$. Diakses tanggal 2 Juni 2015.

Purwanto. (2007) Psikologi Pendidikan. Remaja Rosdakarya, Bandung.

Safitri, F. (2013) "Pengaruh Motivasi dan Dukungan Keluarga terhadap Prestasi Belajar Mahasiswa Tingkat II Prodi D-III Kebidanan Stikes U'budiyah Banda Aceh". http://simtakp.uui.ac.id/dockti/ FARADILLA_SAFITRI-skripsi_dilla.pdf. Diakses tanggal 16 November 2014.

Siswanto, F. Erwin, Woferst, R. (2014). "Faktor-Faktor yang Berhubungan dengan Motivasi Mahasiswa untuk
Melanjutkan Profesi". http://download. portalgaruda. org/article. php?article $=186$ $686 \&$ val $=6447$ \&title=Faktor-Faktor $\% 20$ Yang\%20Berhubungan\%20Dengan\%20 Motivasi\%20Mahasiswa\%20Untuk\%20 Melanjutkan\%20Profesi $\% 20$ Ners. Diakses tanggal 25 Juni 2015.

Suyasa, Rasdini,Adan Suardana, K.I. (2014). Hubungan Antar Dukungan Keluarga Dengan Motivasi Belajar Mahasiswa Program Studi IImu Keperawatan (PSIK) Fakultas Kedokteran Universitas Udayana". http://www.e-jurnal.com. Diakses tanggal 5 Juni 2015.

Pambudi PS dan Wijayanti DY (2012). Hubungan konsep diri dengan prestasi akademik mahasiswa keperawatan. http://jks.fikes.unsoed.ac.id/index.php/ jks/article/download/361/199. Diakses tanggal 31 Desember 2014.

Wulandari, S. (2014). "Hubungan Tingkat Pendidikan Orangtua dengan Prestasi Belajar Siswa Kelas V A di SDN rejondani Madurejo Prambanan Sleman Yogyakarta Semester 1 Tahun Pelajaran 2012/2013". http://digilib.uin-suka. ac.id/11064/. Diakses tanggal 16 Juni 2015 dari.

Yanti, D. (2012). Hubungan Antara Dukungan Keluarga dengan Minat dan Motivasi menjadi Perawat pada Mahasiswa Program Studi IImu Keperawatan Fakultas IImu Kesehatan Universitas Kristen Satya Wacana. http://repository. uksw.edu/handle/123456789/2751. Diakses tanggal 11 Juni 2015. 